\title{
Estimating of Maximum Groundwater Level to Trigger Landslide in Batu Hijau Open Pit Mine, West Nusa Tenggara, Indonesia
}

\author{
Amirul Aiman Abd Karim ${ }^{1}$, Wahyu Wilopo ${ }^{* 1}$, I Gde Budi Indrawan ${ }^{1}$, and Kardiansyah ${ }^{2}$ \\ ${ }^{1}$ Department of Geological Engineering, Faculty of Engineering, Universitas Gadjah Mada, Yogyakarta, Indonesia \\ ${ }^{2}$ Department of Geotechnical \& Hydrogeological, PT. Amman Mineral, West Nusa Tenggara, Indonesia
}

\begin{abstract}
Monitoring groundwater level is crucial in an open-pit mine to avoid any life-threatening incident, such as a landslide. Batu Hijau Pit Mine used a vibrating water piezometer (VWP) to monitor its groundwater level. The purpose of the research is to estimate the maximum groundwater level to trigger a landslide at North-East (section 20) in Batu Hijau Pit Mine using the finite element method, by assuming below 1.2 safety factor is unsafe. The slope stability and groundwater seepage analyses were carried out using the Phase 2 software. The slope stability analysis used line mapping data, borehole data, laboratory data, and geometry of the slope data to create the anisotropy rock mass model. Meanwhile, groundwater seepage analysis used the VWP data for two months, start from October 2019 until November 2019, to understand groundwater seepage. The slope stability analysis was carried out by considering the groundwater seepage for two months. The slope stability analysis indicates that during the time, the safety factor averagely around 1.32. Estimating maximum groundwater level is being carried out by increasing the reading of VWP $10 \mathrm{~m}$ for each analysis until the safety factor reaches below 1.2. The results show that the safety factor decreases and reaches 1.18 when VWP's increment is about 70 m. In a nutshell, the North-East (Section 20) slope will trigger a landslide if the groundwater level increases up to $70 \mathrm{~m}$ by neglecting the area's excavation activity, which may increase the pores between the rocks and decrease the strength of the rock mass.
\end{abstract}

Keywords: Landslide · Anisotropy rock mass model - Groundwater level · Safety factor . Batu Hijau · Finite element method.

\section{INTRODUCTION}

Climate change triggered an increase in rainfall. In Indonesia, extreme weather usually comes in contrast. For example, a day may include hot weather followed by sudden, swift rain (Irwansyah, 2016). This climate will inevitably affect slope stability, especially during the heavy rain seasons. This natural phenomenon could not be stopped, but the slope's failure could be minimized by monitoring the groundwater table during that time. The evaluation and management of water during the time are becoming

\footnotetext{
${ }^{*}$ Corresponding author: W. WILOPO, Department of Geological Engineering, Universitas Gadjah Mada. Jl. Grafika 2 Yogyakarta, Indonesia. E-mail: wilopo_w@ugm.ac.id
}

crucial for mine operators. It is including the control and management of groundwater and surface water within and around the open pit (Beale and Read, 2013). There are many adverse effects of uncontrolled groundwater within and around the open-pit mine, such as slope failure. It will mainly affect the performance and economics of mining operations. Depending on the intensity of the rainfall event and the soil's antecedent conditions, a proportion of the rainfall would form runoff, and a proportion will infiltrate (Beale and Read, 2013). The worst-case scenario can lead to the injury or death of the employee.

Batu Hijau Open Pit Mine is located in western Sumbawa Island in Sekonkang Sub-district, 
West Nusa Tenggara Province, Indonesia, operated by PT Amman Mineral Nusa Tenggara (PTAMNT). The monitoring of groundwater level in Batu Hijau Pit Mine is by installing the vibrating water pressure (VWP) equipment at several points to monitor the change in groundwater from time to time. Batu Hijau Pit Mine's groundwater level may change due to heavy rainfall or constant excavation activity, which may disturb the pores within the rocks. The infiltration of rainfall into a slope may decrease the slope stability (Kim et al., 2004; Suradi et al., 2015). The excessive rains may reduce the negative pore pressure towards zero and even become positive with rising the water table due to rainfall infiltration (Yiming et al., 2019). The consequences can increase the material's weight, resulting in an increase in effective sliding force and reduce the shear strength of the material or rock slope (Li et al., 2019). The mechanism of slope failure due to rainfall infiltration has become widely accepted as a plausible explanation for such failures (Suradi et al., 2015). Given that the rate of change of pore pressure is related to the amount of water that penetrates a soil or rock slope, including rainfall duration and intensity are critically important and must be accounted for. The mining company can also use a high volume pumping system to pump out the water from the pit bottom (Beale and Read, 2013).

The problem explaining above also occur in the Batu Hijau Pit Mine. There are several mitigations efforts taken by the PT AMNT to reduce the risk of the slope failure as suggested by Beale and Read (2013), which consider doing Horizontal Drilling (HD) to decrease the groundwater table so they can control the stability of the slope and maintain the angle of the overall slope. Therefore the research aims to estimate the maximum level of groundwater to cause the landslide.

\section{RESEARCH AREA}

The research area is located in the pit PT Amman Mineral Nusa Tenggara (PT AMNT), western of Sumbawa Island in Sekongkang Subdistrict, West Sumbawa District, West Nusa Tenggara Province, Indonesia, as shown in Figure 1. The mining location is within Batu Hijau porphyry, which is rich in gold and copper min- eralization. They are using an open-pit mining method to extract gold and copper. The mining area's development started from early 2000 until today, which pit bottom is about to reach around -390 m below sea level. Until 2019, the mine's development is at Phase 6 and planning to proceed to Phase 7 (AMNT, 2019a), which requires a more complex model to be analyzed to gain a higher confidence level of stability. This article's phase-in is the mining activity to extract the rock from time to time, depending on the condition. A complex model in this research can be defined as a model that includes the configuration of the structure or discontinuity, the rock mass characterization data, borehole, and the groundwater table level.

Batu Hijau formation's stratigraphy starts from old to young, volcanic rock and andesite porphyry unit, diorite unit, and tonalite unit. The volcanic rock and andesite porphyry unit consists of fined-sized volcaniclastic rock (fine Tuff), a crystal tuff, and a porphyritic intrusion. The second intrusion is a porphyritic quartz diorite and a granular quartz diorite. These rock series were intrusion by the old tonalite rocks and young tonalite rocks (Garwin, 2002). In some places, the rock was found been undergo several alteration processes with clay mineral composition during the time. Due to the properties of clay mineral, it usually will absorb and store water, thus disturb the groundwater level and potentially reducing slope stability (Beale and Read, 2013).

West Sumbawa District has an average of about 13.5 days raining with $168.42 \mathrm{~mm}$ rainfall the year 2018 (BPS Sumbawa Barat District, 2019), which most of it occurs at the beginning and end of the year, which can achieve up to $558 \mathrm{~mm}$ rainfall maximum per month with 22 days of rain. The VWP groundwater level reading could increase and decrease to $30 \mathrm{~m}$ and $20 \mathrm{~m}$, respectively (Yudhanto, 2019). His research concludes that the groundwater is mostly coming out from the installation drain hole at about $33.133 \mathrm{~m}^{3} /$ day. Besides, the groundwater level's influence on the rock mass's strength will decrease slope stability (Faturrahman, 2019). The water pressure will increase the driving forces of the rock slope and cause the slope to fail. Therefore, there is much debris falls in the mining area. The 


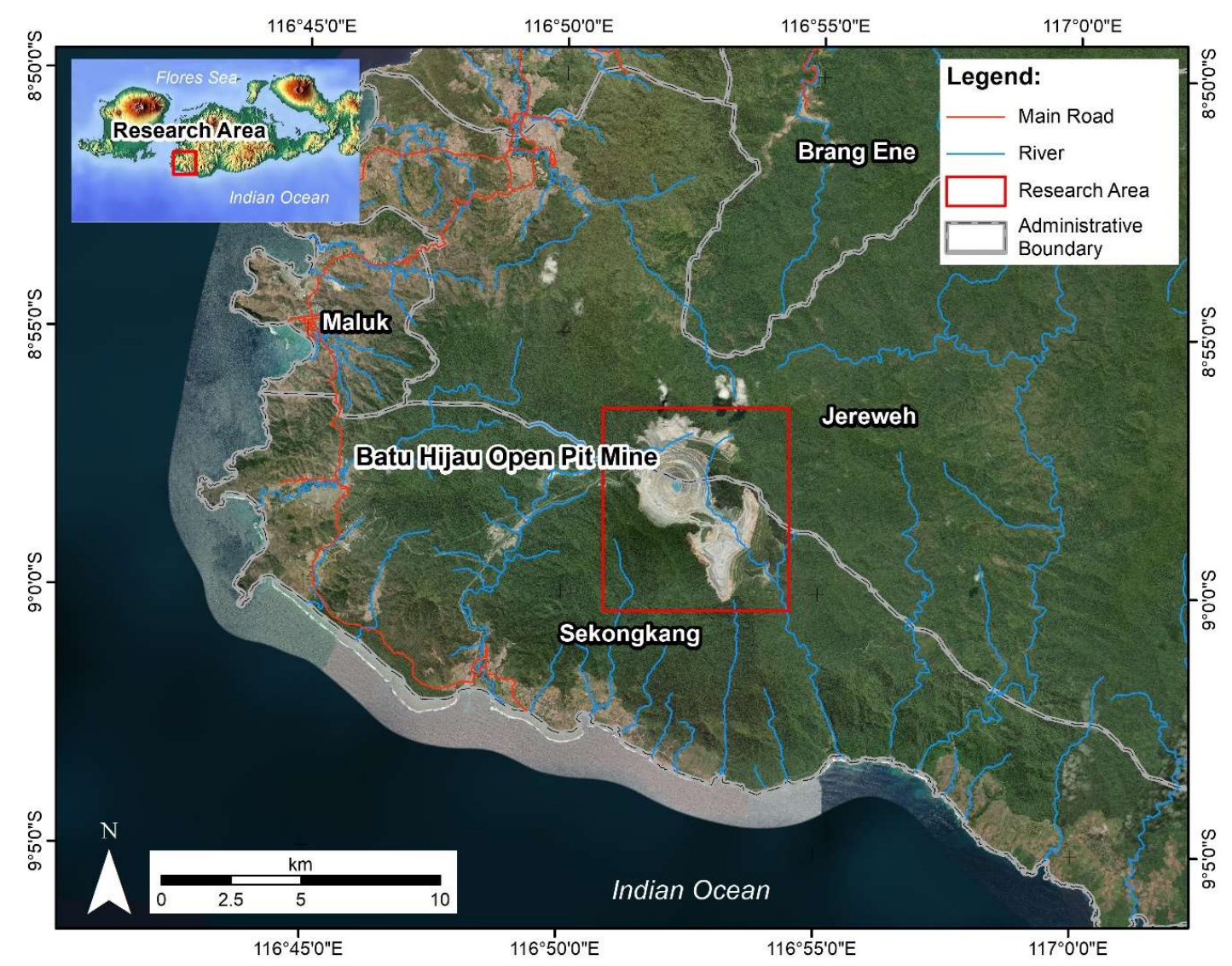

FIgURE 1. Location of Batu Hijau Open Pit Mine, PT Amman Mineral Nusa Tenggara.

pit's inter-ramp's critical slope was determined based on the safety factor with a value below 1.2 (Wesseloo and Read, 2009).

The research area was at the North-East (section 20) of the Batu Hijau Pit Mine. Three types of rock exist within the research area (AMNT, 2019a), volcanic, diorite, and tonalite. Two vibrating water pressure (VWP) equipment is installed near the cross-section area within the slope area, as shown in Figure 2. These two VWP data will help create the model groundwater table, which will be used in slope stability analysis. The alteration at North-East (section 20 ) is considered high since clay type material causes the groundwater to be further from the wall due to clay material properties.

\section{METHOD}

The research has been conducted by collecting the necessary input data to simulate the maximum groundwater level to cause a landslide, including primary and secondary data. Primary data line mapping data is used as the data taken along the research slope and combined with existing data owned by PT AMNT. The data later will be useful in describing the joint (discontinuity) within the slope in the slope model. Secondary data used is provided by PT AMNT, which includes the vibrating water piezometer (VWP) data (2 piezometers) for two months, the borehole, laboratory data, and geometry of the slope. The VWP data used starting from October 2019 until November 2019 for both piezometers. The geotechnical parameters data is obtained from the borehole data and laboratory data, including the uniaxial compressive stress (UCS) and the intact rock constant, $\mathrm{mi}$, which later will be used to satisfy the Generalise Hoek \& Brown criterion. The geometry of the slope helps in illustrate the slope section into the Phase2 software for the analysis.

The slope stability analysis was conducted using the Phase 2 analysis, highlighting the finite element analysis method for this research. The finite element method is one of the numerical analysis. It can model many of the complex conditions found in rock slopes, such as nonlinear stress-strain behavior, anisotropy, and geometry (Read and Stacey, 2009). The slope stability analysis is based on the strength reduc- 
KARIM et al.

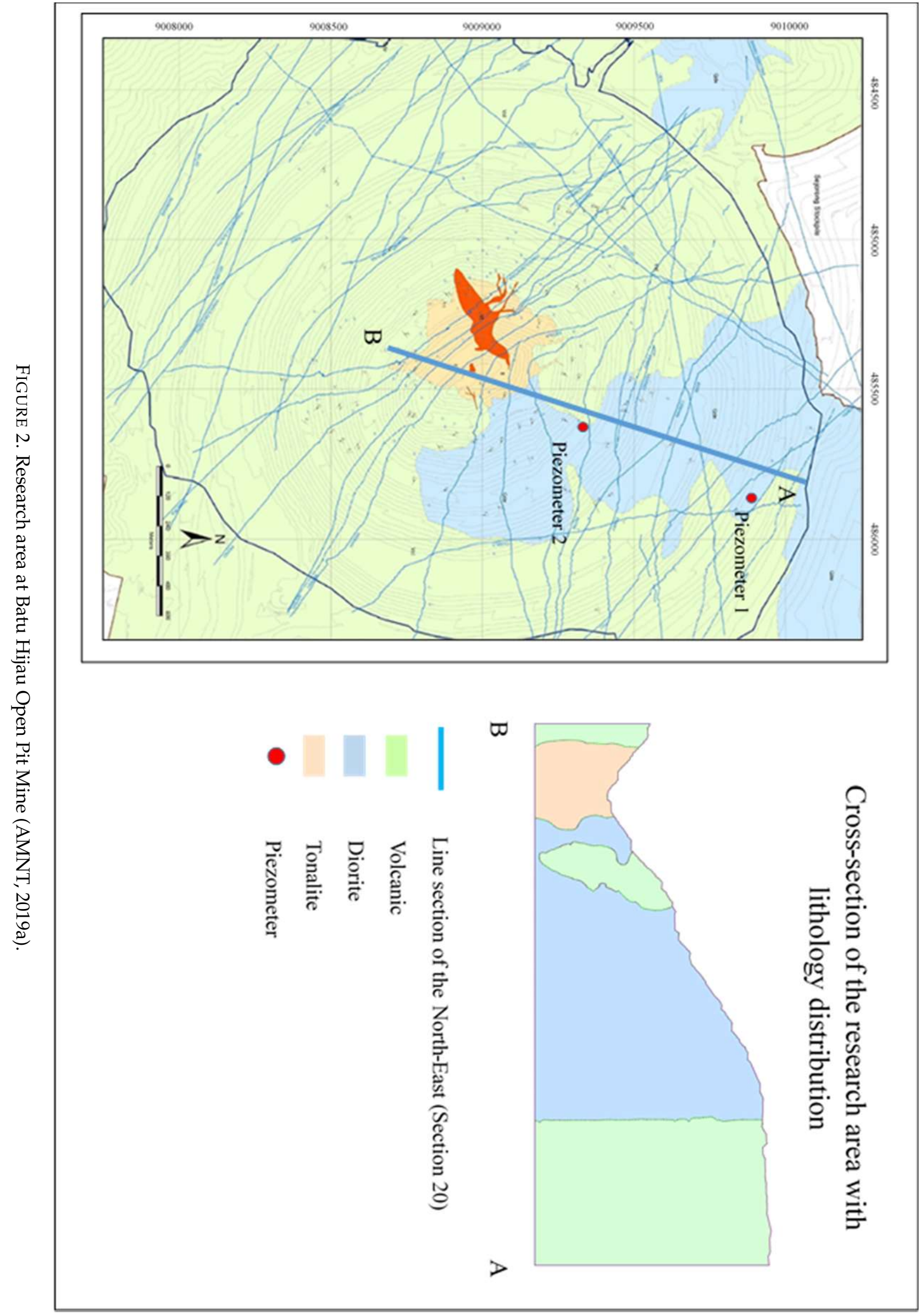


tion factor and the Generalise Hoek \& Brown criterion for material characteristics. Assuming the Mohr-Coulomb failure criterion is used; thus, the shear strength reduction can be determined from this equation:

Original Mohr-Coulomb equation

$$
\tau=c^{\prime}+\sigma^{\prime} \tan \varphi
$$

where $\tau=$ shear strength; $c=$ cohesion; $\sigma^{\prime}=$ normal stress and $\varphi=$ angle of internal friction

Reduced strength Mohr-Coulomb equation

$$
\tau=\frac{c^{\prime}}{F}+\frac{\sigma^{\prime} \tan \varphi}{F}
$$

where $F$ is the safety factor

For this rock masses model, the author decided to use the Generalized Hoek-Brown criterion as it is the most commonly applied strength model for rock masses (Hammah et al., 2005) and can be expressed as:

$$
\sigma_{1}^{\prime}=\sigma_{3}^{\prime}+\sigma c_{i}\left(m \frac{\sigma_{3}^{\prime}}{\sigma c_{i}}+s\right) \alpha
$$

where $\sigma_{1}^{\prime}$ and $\sigma_{3}^{\prime}$ are the major and minor effective principal stresses at failure $\sigma c_{i}$ is the uniaxial compressive strength of the intact rock, while

$$
\begin{gathered}
m=m_{i} \exp \left(\frac{\mathrm{GSI}-100}{28-14 D}\right) \\
s=\exp \left(\frac{\mathrm{GSI}-100}{9-3 D}\right) \\
\alpha=\frac{1}{2}+\frac{1}{6}\left(e^{-\frac{\mathrm{GSI}}{15}}-e^{-\frac{20}{3}}\right)
\end{gathered}
$$

where $m$ is a reduced value of intact rock constant $m_{i}$, while $s$ and $\alpha$ are constant depending on the rock mass properties, GSI is the geological strength index, and $D$ is the disturbance factor. The value for GSI used for the analyses is coming from the conversion of rock mass rating (RMR) data provided by PT AMNT and can be determined from this equation;

$$
\mathrm{GSI}=\mathrm{RMR}-5
$$

Next, the groundwater model is generated from Phase 2 using the finite element analysis method for groundwater seepage. As for the groundwater model, the author used the option prepared by Rocscience Phase 2 software, which is a FE analysis for groundwater seepage. The Phase 2 software will compute a steady-state seepage to determine the pore pressure distribution based on the groundwater boundary conditions. By using this option, the groundwater flow would be affected by the hydraulic conductivity of each material. The groundwater model later will be increased by using a trial and error method by assumed $10 \mathrm{~m}$ increment for each analysis until the safety factor reaching below 1.2 as suggest by Wesseloo and Read (2009).

\section{Result AND Discussion}

\subsection{Slope condition}

\subsubsection{Discontinuity}

In general, the slope's failure at the Batu Hijau Pit is mainly controlled by a discontinuity, so it is essential to consider the discontinuity within the area. Thus, the author decided to used the anisotropic rock mass model where the parallel deterministic fracture is included in the model to make the model more realistic. Therefore, the joint's dip to include must be determined by finding the joint's apparent dip. The apparent dip in the inclination of a geological bed in the cross-section is not perpendicular to the strike, while the true dip in the cross-section is perpendicular to the strike of the bed. Numbers of joints data were used and analyzed in Dips software to find the joint's representative dip and dip direction at the research area, affecting the slope stability, and converted to apparent dip to include in the slope model.

The domain (Domain 1, Domain 2, Domain 5, Domain 8, Domain 10), as shown in Figure 3, is created by PT AMNT to understand the discontinuities within the area easily. The domain majorly influences by the major fault exist within the area and combine with other data such as borehole data to be grouped into classes. Table 1 shows the apparent representative dip generated from the Minesight software. Each domain has its representative joint to represent the discontinuity within the domain. Most of the domain has only one representative joint except for domain five, which has two sets of a joint: $\mathrm{J} 1$ and J2, as shown in Table 1. Table 2 shows the data used for the spacing, length, and persistence of the joint to be included for 
the company's slope stability analysis. Figure 3 shows the complete slope model with about $550 \mathrm{~m}$ height with a major fault and joint network for the slope stability analysis. The generalized Hoek \& Brown is used to define rock strength properties, as discussed earlier. Figure 4 shows the color within the model to differentiate the rock mass rating (RMR) within the slope's cross-section since the generalized Hoek \& Brown required the GSI data.

\subsubsection{Geotechnical parameter}

The data for the material to be included in the rock mass model is obtained from the PT AMNT laboratory test, as shown in Table 2. It includes the uniaxial compressive stress (UCS), disturbing factor, D, and rock mass constant, mi. With data provided, Phase 2 program, later on, will automatically generate the other constant based on Hoek \& Brown data suggestions such as $\mathrm{mb}$, s, and a, as explained earlier in the method. As for the disturbance factor, two values, which are 0.7 and 1 , were used to differentiate the blasting effect since PT AMNT used pre-split in blasting activity.

\subsubsection{Groundwater model}

The modeling of groundwater for research area North-East (section 20) is based on the piezometer data collected in the form of pressure $(\mathrm{kPa})$ then converted into the total head to be useful in Rocscience Phase2 software. The hydraulic conductivity $(K)$ data (Table 3 ) used for the groundwater model is obtained from the PT AMNT laboratory data and supported by the evaluation of water in pit slope stability by Beale and Read (2013). K2/K1 is a factor that specifies the relative permeability in the direction orthogonal to the $\mathrm{K} 1$ direction. Note that the K1 permeability is the "primary" permeability defined by the Saturated Permeability Ks and the unsaturated permeability model (Solomon and Ekolu, 2009). Table 4 shown the groundwater level of the slope for two months for both piezometers. These data will analyze the slope stability and estimate the groundwater limit for the slope to fail. The trial and error method will be used by increasing the slope's groundwater level until the safety factor reaches below 1.2 based on Wesseloo and Read (2009).
The groundwater model is assumed to be representative when one of the piezometer's pore pressure is about the same as the field data were taken. The groundwater table's depth has been adjusted from the original groundwater model until the safety factor reaches below 1.2. The value of the original groundwater used is from date November 28, 2019. A $10 \mathrm{~m}$ increment will be used from the original groundwater data for each analysis until the safety factor reaches below 1.2. $10 \mathrm{~m}$ increment is used because the result of analyses shows a significant change in the safety factor. The groundwater level was increased by increasing the reading of both piezometers with a $10 \mathrm{~m}$ increment, and the Phase 2 program will generate a new groundwater model, as shown in Figure 5.

\subsection{Slope stability analysis}

The analysis for slope stability was done using a strength reduction factor (SRF) method in which the strength of the material was tested or stressed until it becomes a residual. Using the cross-section of the North-East (section 20) slope, as shown in Figure 2, the groundwater limit can be simulated using an SRF method of analysis. The analysis has been done, by considering groundwater level data starting from October 1, 2019, until November 28, 2019, to observe the change in a safety factor using original field data, as shown in Figure 6.

The groundwater limit estimation has been done using several groundwaters level data to get the value of the safety factor below 1.2. The increment was made with an increasing groundwater level from the original groundwater level with $10 \mathrm{~m}$ for each analysis to observe the change in the safety factor value. The results showed a difference in the safety factor when the groundwater level was increased from time to time, as shown in Figure 7. Until it reaches a $70 \mathrm{~m}$ increment, we can see the slope stability starts to drop below the 1.2 safety factor value. Previous research has been done by Yudhanto (2019), which simulates a groundwater model, concludes that there is fluctuation about $30 \mathrm{~m}$, and increases in groundwater level about $20 \mathrm{~m}$ at a particular reading of the VWP Batu Hijau Pit Mine. The increment may occur if there is no excavation activity near the research area. The increasing groundwater level closed to the wall 


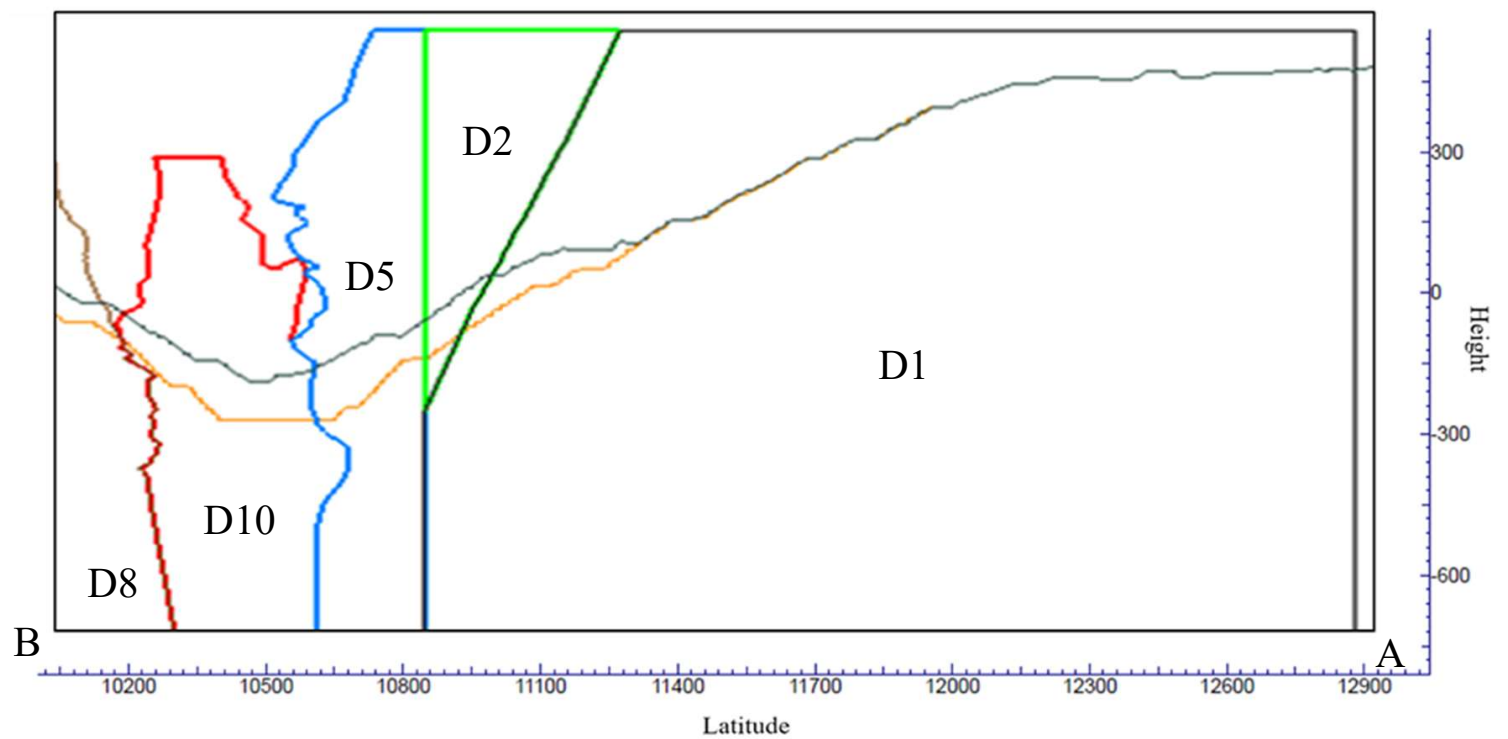

FIGURE 3. Classification of the domain within the research area North-East (section 20) (modified from AMNT, 2019b).

TABLE 1. Shown the joint network data for each of the apparent dip generated from Dips software for discontinuity within the domain at the North-East (section 20).

\begin{tabular}{lcccccc}
\hline Domain & Dip Direction $\left(^{\circ}\right)$ & Dip $\left(^{\circ}\right)$ & Apparent Dip $\left(^{\circ}\right)$ & $\begin{array}{c}\text { Spacing } \\
(\mathrm{m})\end{array}$ & $\begin{array}{c}\text { Length } \\
(\mathrm{m})\end{array}$ & $\begin{array}{c}\text { Persistence } \\
(\mathrm{m})\end{array}$ \\
\hline D 1 & 196 & 44 & 43.93 & 16.75 & 22.25 & 0.5 \\
D 2 & 237 & 68 & 63.17 & 5 & 12.84 & 0.5 \\
D 5 & $315(\mathrm{~J} 1) / 330(\mathrm{~J} 2)$ & $41(\mathrm{~J} 1) / 70(\mathrm{~J} 2)$ & $20.17(\mathrm{~J} 1) / 60.48(\mathrm{~J} 2)$ & 5 & 12.62 & 0.5 \\
D 8 & 211 & 56 & 123.49 & 14 & 17.32 & 0.5 \\
D 10 & 242 & 36 & 151.63 & 3 & 13.5 & 0.5 \\
\hline
\end{tabular}

TABLE 2. Geotechnical parameter data (AMNT, 2019c).

\begin{tabular}{lccc}
\hline Lithology & Disturbing Factor, $D$ & $\begin{array}{c}\text { Uniaxial Compressive } \\
\text { Stress, UCS }(\mathrm{kPa})\end{array}$ & Rock Mass Constant, $m_{i}$ \\
\hline \multirow{2}{*}{ Volcanic } & 0.7 & 68332 & 25 \\
& 1.0 & 68332 & 25 \\
\hline \multirow{2}{*}{ Diorite } & 0.7 & 61226 & 25 \\
& 1.0 & 61226 & 25 \\
\multirow{2}{*}{ Tonalite } & 0.7 & 79604 & 29 \\
& 1.0 & 79604 & 29 \\
\hline
\end{tabular}

TABLE 3. Value of hydraulic conductivity of the material used for analysis based on laboratory data and references value (Beale and Read, 2013).

\begin{tabular}{lcc}
\hline Lithology & Hydraulic Conductivity, K (m/s) & K2(vertical) / K1(horizontal) \\
\hline NE Inner Volcanic & $8.00 \mathrm{E}-08$ & 0.3 \\
NE Outer Volcanic & $9.00 \mathrm{E}-08$ & 1.0 \\
Diorite & $9.50 \mathrm{E}-08$ & 0.9 \\
Tonalite & $1.00 \mathrm{E}-06$ & 1.0 \\
Fault & $1.00 \mathrm{E}-11$ & 1.0 \\
\hline
\end{tabular}




\section{KARIM et al.}

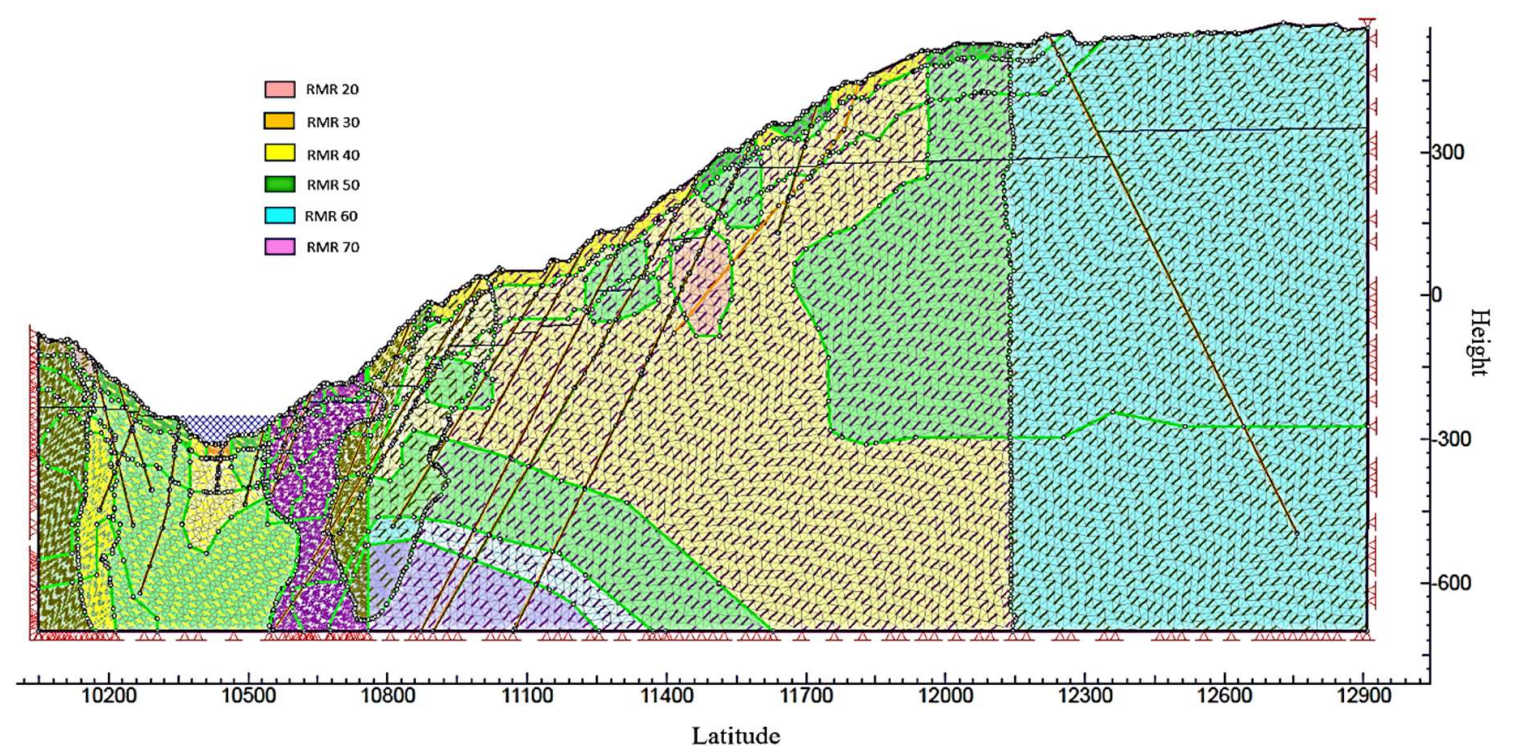

FIGURE 4. Anisotropic rock mass model of the North-East (section 20) for slope stability analysis with rock mass rating, discontinuity, and fault data.

TABLE 4. The groundwater level data for each vibrating piezometer for two months (AMNT, 2019d).

\begin{tabular}{lcc}
\hline Date & Piezometer 1(m-SWL) & Piezometer 2 (m-SWL) \\
\hline Oct 1, 2019 & 264.8 & -208.64 \\
Oct 7, 2019 & 264.49 & -208.84 \\
Oct 21, 2019 & 263.77 & -208.69 \\
Oct 28, 2019 & 263.52 & -208.7 \\
Nov 1, 2019 & 263.14 & -208.8 \\
Nov 7, 2019 & 263.01 & -208.7 \\
Nov 14, 2019 & 262.46 & -208.6 \\
Nov 21, 2019 & 261.99 & -208.8 \\
Nov 28, 2019 & 261.8 & -208.7 \\
\hline
\end{tabular}

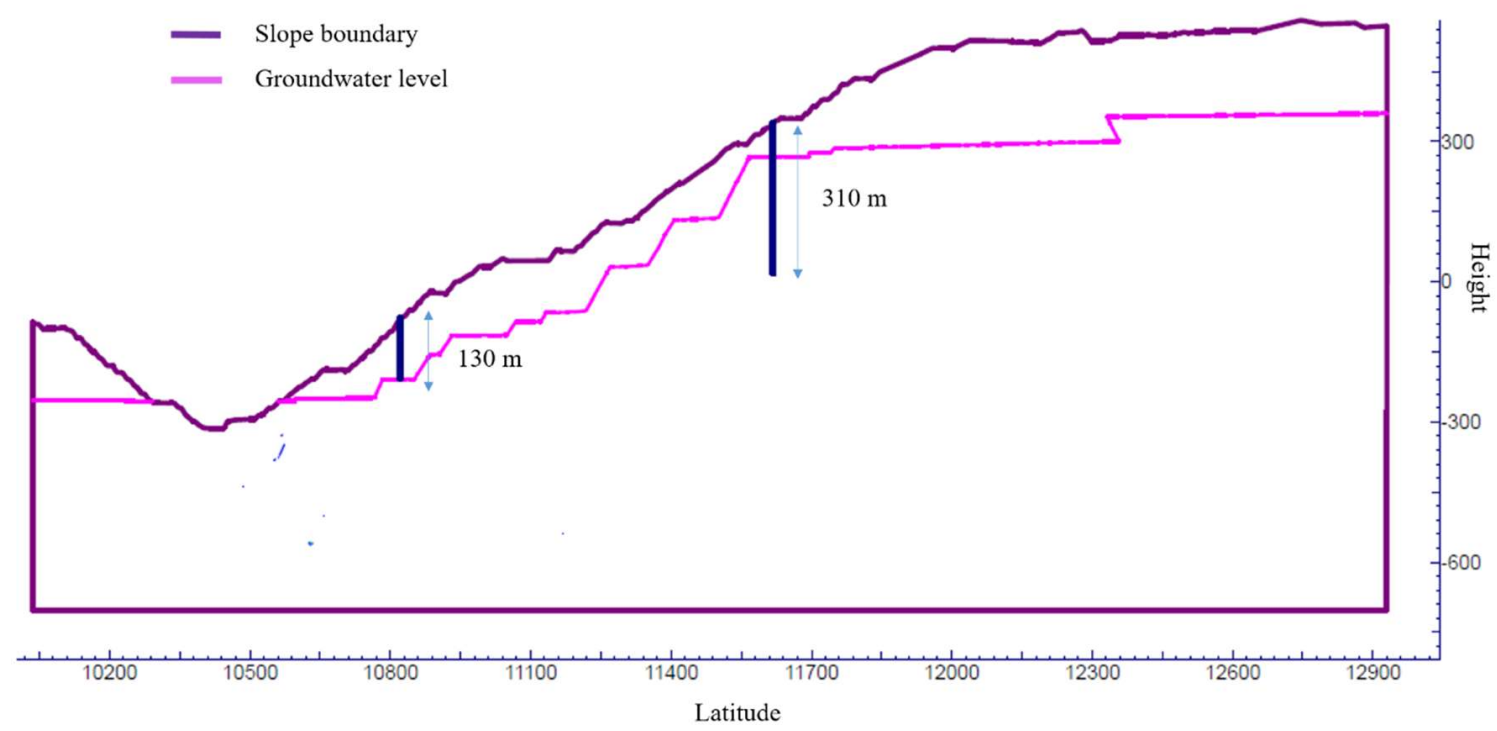

FIGURE 5. Groundwater condition. 


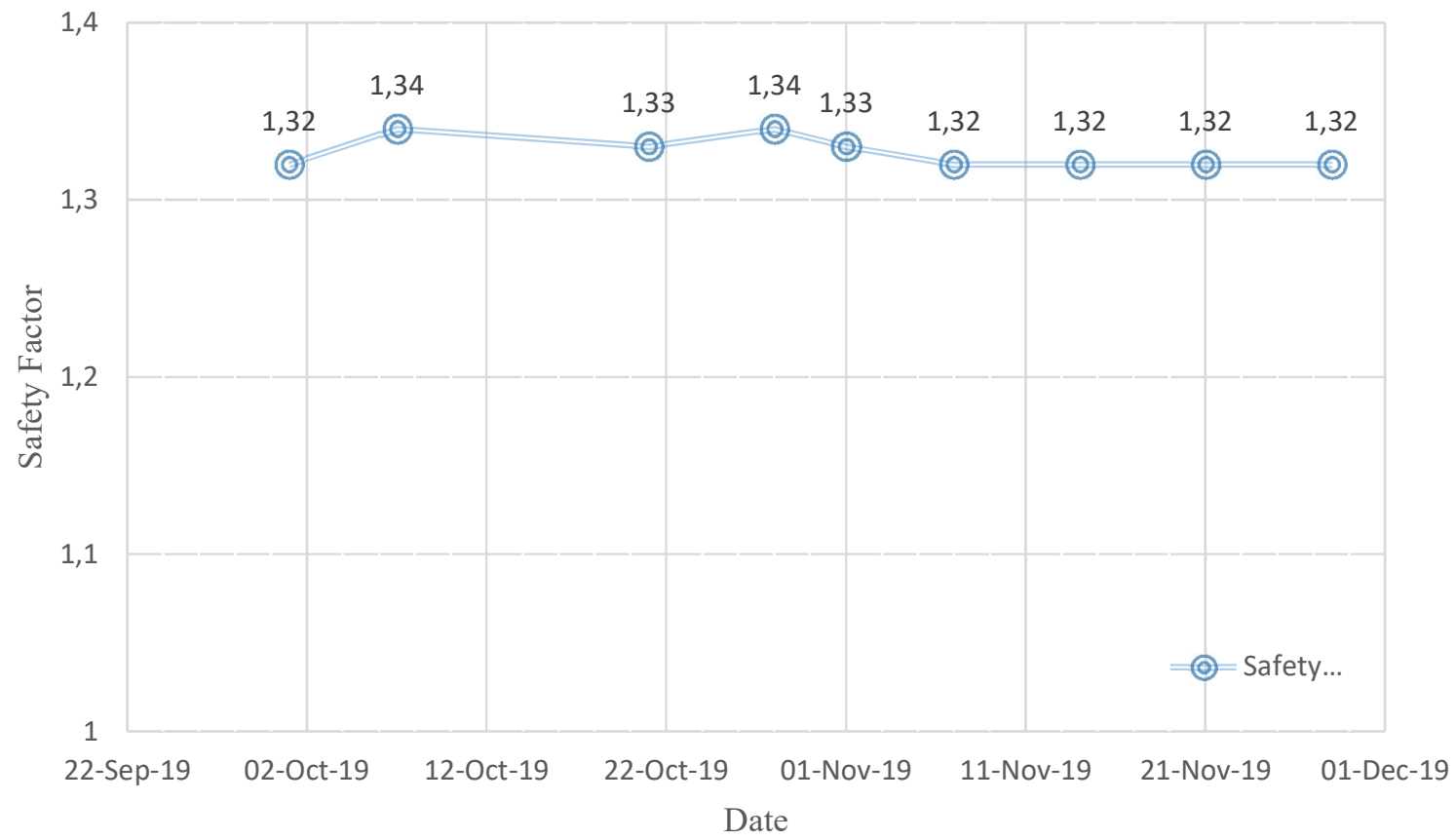

FIGURE 6. Result of the slope stability analysis (weekly) for two months.

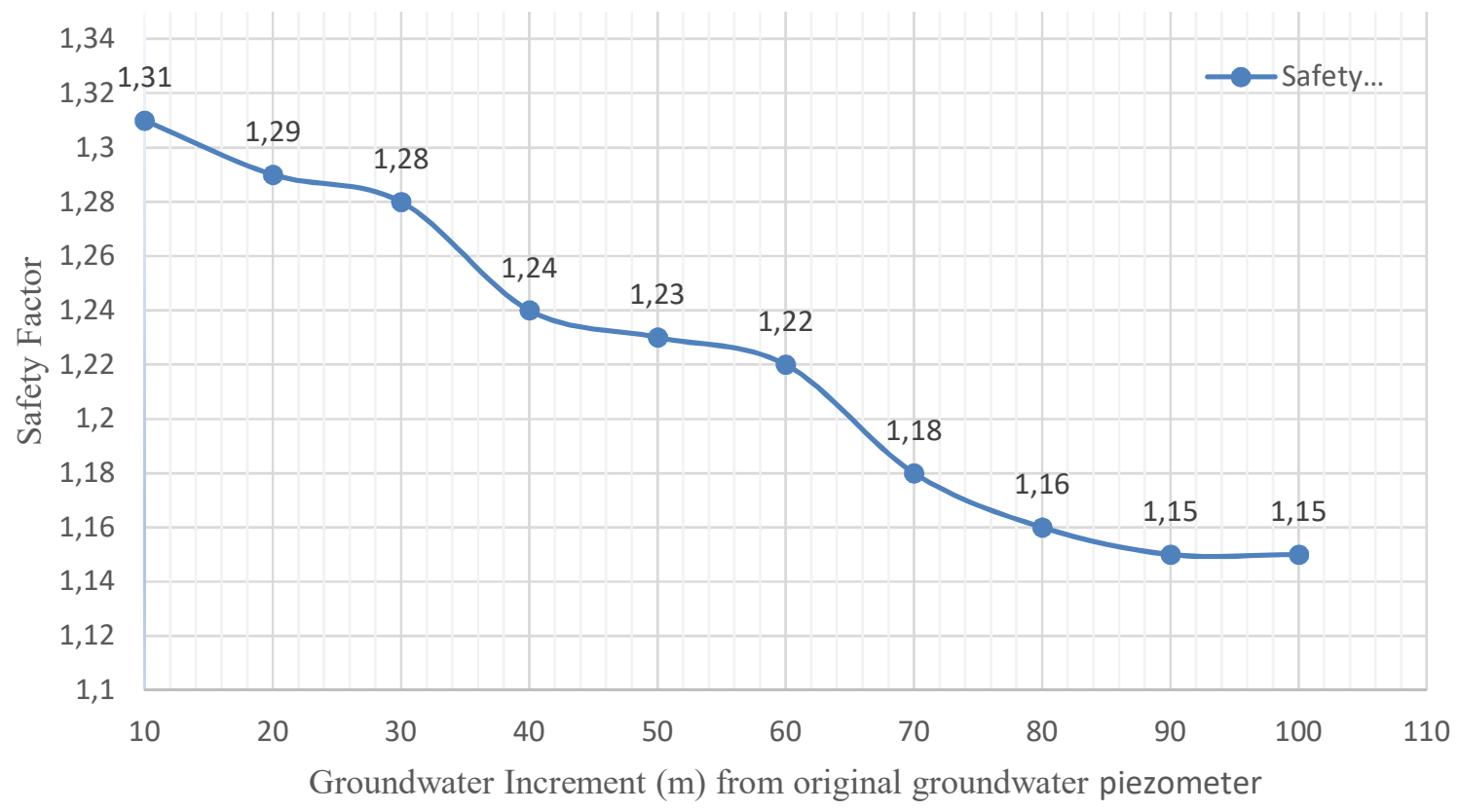

FIGURE 7. Result of the slope stability analysis after the increment of the groundwater table. 
surface will be following by a decreasing slope safety factor.

\section{CONCLUSION}

The maximum groundwater level to cause landslide is at $70 \mathrm{~m}$ increment onwards with the existing slope. The condition is reached by neglecting the excavation activity in the research area during the analysis. Initially, the slope stability analysis results indicated that the slope at North-East (Section 20) is in a stable state with an average of 1.32 safety factor. The slope's safety factor shows a decreasing trend as a 10 $\mathrm{m}$ increment of groundwater level is given to the VWP reading. Increasing the groundwater level will reduce the shear strength of the material within the slope and leads to the landslide. The slope will be unstable (safety factor reaches below 1.2) when the increment is at $70 \mathrm{~m}$ with safety factor 1.18 .

\section{ACKNOWLEDGEMENTS}

The author would like to thanks PT. Amman Mineral Nusa Tenggara for their permission to researched Batu Hijau. Not to forget the staff in the Geotechnical and Hydrogeological Department that contributed to this research.

\section{REFERENCES}

AMNT (2019a) Geological Interpretation Map Data, PT Amman Mineral Nusa Tenggara (unpublished report).

AMNT (2019b) Geotechnical Line Mapping Data, PT Amman Mineral Nusa Tenggara (unpublished report).

AMNT (2019c) Laboratory Test Data, PT Amman Mineral Nusa Tenggara (unpublished report).

AMNT (2019d) Groundwater Data (Monthly), PT Amman Mineral Nusa Tenggara (unpublished report).

Bar, N. and Mcquillan, A. (2018) 3D Limit Equilibrium Slope Stability Analysis for Anisotropic and Faulted Rock Masses in Australian Coal and Iron Ore Mines ARMS10: 10th Asian Rock Mechanics Symposium (ISRM International Symposium for 2018). 12p.

Beale, G. and Read, J. (2013) Evaluating Water in Pit Slope Stability. CSIRO Publishing, 600p.

BPS Sumbawa Barat District. (2019) Jumlah Curah Hujan dan Hari Hujan di Kecamatan Sekongkang dan Sekitarnya. Available at: https://sumbawabaratkab.bps.go.id/statictable/ 2018/10/18/311/jumlah-curah-hujan-danhari-hujan-di-kecamatan-sekongkang-dansekitarnya-2018.html(Accessed: 13 July 2019)

Carlile, J. C., and Mitchell, A. H. G. (1994) Magmatic arcs and associated gold and copper mineralization in Indonesia, Jurnal of Geochemical Exploration, 50(1-3), pp. 91-142.

Faturrahman, D. P. (2019) Analisis Kestabilan Lereng Guna Mengoptimalkan Desain Pit Bottom Phase 7 PT. Amman Mineral Nusa Tenggara Kabupaten Sumbawa Barat. Universitas Pembangunan Nasional 'Veteran', 76p.

Garwin, S. (2002) The Geologic Setting of IntrusionRelated Hydrothermal Systems near the Batu Hijau Porphyry Copper-Gold Deposit, Sumbawa, Indonesia. In R. J. Goldfarb \& R. L. Nielsen (Eds.), Integrated Methods for Discovery: Global Exploration in the Twenty-First Century (Denver, Co, Vol. 9), pp. 333-366.

Griffiths, D. V., and Lane, P. A. (1999) Slope stability analysis by Finite Elements, Géotechnique, 51(3), pp. 387-403.

Hammah, R., Yacoub, T. and Corkum, B. (2005) The Shear Strength Reduction Method for the Generalized Hoek-Brown Criterion, in Alaska Rocks 2005, The 40th U.S. Symposium on Rock Mechanics (USRMS): Rock Mechanics for Energy, Mineral and Infrastructure Development in the Northern Regions. Anchorage, Alaska. 7p.

Irwansyah (2016) What do scientists say on climate change? A study of Indonesia newspaper, Pacific Science Review B: Humanities and Social Sciences, pp. 58-68

Kim, J., Jeong, S., Park, S., and Sharma, J. (2004) Influence of rainfall-induced wetting on the stability of slopes in weathered soils, pp. 251-262.

Li, Y., Xiao, T., Cao, Z. J., Phoon, K. K., and Zhou, C. B. (2019) Slope stability analysis with reference to rainfall infiltration in the Yongping Copper, 116(4), pp. 536-543.

Read, J. and Stacey, P. (2009) Guidelines For Open Pit Slope Design. CSIRO Publishing, 496p.

Suradi, M., Fourie, A. B. and Saynor, M. J. (2015) An experimental and numerical study of a landslide triggered by an extreme rainfall event in northern, pp. 1125-1138.

Wen, A., Sturzenegger, M., and Stead, D. (2014) Analysis of a Complex Rock Slope Instability with a Stepped Failure Surface using Discrete Fracture Network Models, (October), in International Discrete Fracture Network Engineering Conference (DFNE 2014). $10 \mathrm{p}$.

Wesseloo, J. and Read, J. (2009) Acceptance Criteria, in Guidelinefir Open Pit Slope Design. CSIRO Publishing, pp. 221-235.

Yiming, W., Siame, T. and Bowa, V. M. (2019) Ef- 
Estimating of MAXimum Groundwater LeVel to Trigger LANDSLide in BAtu Hijau Mine

fects of Rainfall Patterns on The Stability of Upper Stack of Open Pit Slopes, (March), pp. 51-61

Yudhanto, B. A. (2019) Pemodelan Airtanah pada Pit

Batu Hijau PT Amman Minerak Nusa Tenggara,
Kabupaten Sumbawa Barat, Provinsi Nusa Tenggara Barat. Universitas Pembangunan Nasional 'Veteran', 45p. 